\title{
A Dynamic Analysis of The Relationship Between Monetary Policies and Loan Risk Exposures in Nigerian Deposit Money Banks
}

\author{
Omankhanlen Alex Ehimare (Ph.D) \\ Department of Banking and Finance, School of Business, College of Business and Social Sciences, Covenant University \\ Ota, Ogun State, Nigeria; E-mail:alexehimare@yahoo.com, alexander.omankhanlen@covenantuniversity.edu.ng

\section{Okorie Uchechukwu Emena} \\ Department of Economics, School of Social Sciences, College of Business and Social Sciences \\ Covenant University, Ota, Ogun State, Nigeria; ucheson4excel@yahoo.com \\ Taiwo J. Niyan (Ph.D) \\ Department of Banking and Finance, School of Business, College of Business and Social Sciences \\ Covenant University, Ota, Ogun State, Nigeria; E-mail:joseph.taiwo@covenantuniversity.edu.ng
}

\section{Doi:10.5901/mjss.2015.v6n6p247}

\begin{abstract}
This work investigated the effects Monetary Policy has on Loan Risk Exposure in Nigeria Commercial Banks. Nigerian banks do not believe much in giving out loans and advances to much of the countries manufacturing and agro based businesses because of the perceived risk associated with lending to these businesses. This has prevented funds from getting to businesses that can help grow the economy. The data analysis of this study was carried out with ordinary least square multivariate regression perspective within the confinement of a vector error correction model (VECM) framework. The result of this study reveals that lending rate does not play significant role in support of loans and advances. However, monetary policy rate reveal the most significant effect on commercial banks loans and advance confirmed by its efficient estimate. This means that monetary policy rate is a competent parameter in measuring the performance of banks in the allocation of their credit facilities. Based on the findings, it is suggested that the monetary authorities give opportunity for the full interplay of the market forces of supply and demand in the allocation of credit. This interplay should be closely monitored to prevent banks from creating artificial scarcity of funds in order to hike their lending rate.
\end{abstract}

Keywords: Monetary Policy, Banks And Loans And Advances

\section{Introduction}

The financial sector is mainly significant to formal activities that are relevant to the economic activities in Nigeria. This has made it mandatory for monetary policy instruments to become crucial in driving the activities of the Nigeria economy. It has therefore been well observed in Nigeria as well as all other developing countries that prudent monetary policies are the key stone to effective regulations as well as supervision for the growth of any country's banking Industry. By effective manipulation of monetary instruments, the growth rate in the supply of money can be influenced by the Central bank in many ways, namely, availability of credit interest rate level and availability of liquidity from the banking sector. All these can affect the investment, production, consumption of individual as well as government spending. Omankhanlen (2014). Business cycle evenness, financial crisis prevention, rate of interest stabilization in the long run, the rate of exchange in real terms has recently been identified as objectives supplenmentary to monetary policies due to global financial crisis weaving which overwhelmed both emerging and developed economies of the world (Mishra and Pradhan 2008) as cited by Ajayi and Atanda (2012).Nigerian banks generally believe that there is great risk in lending to the manufacturing and agricultural sectors of the economy, hence, their apathy in giving credit to these sectors of the economy, though these sectors hold the key to the development of the economy especially in employment and foreign exchange generation.

\subsection{Statement of the Research Problem}

With the commencement of the Central Bank of Nigeria (CBN) operations in 1959, there was the need by the government 
through the CBN to use monetary policy to drive the economy. This was further given a push by the banking crisis of the 1950s. The Central Bank of Nigeria 2010 monetary policy tightening stance was to enhance the banking system's performance through monetary policies; so much pressure was mounted on the Exchange Rate (ER) and external reserves which led to a fall in the value of the Naira. In addition the interest rate charged by banks for credit has continue to rise, thereby causing much distortion in the financial intermediation process leaving the increase in interest rate unchecked and performance of credit extended by banks to the general public unstable, even in the light of slight inflationary pressures. The refusal of some banks to adhere to the stipulated requirements for issuing of loans and advances to customers has caused the many set-backs in the achievement of the desired macroeconomic objectives.

Many banks stated their reason for high monetary policy rate as the rate issued by the monetary policy committee. This rate for the period under study stands at $12 \%$, which is very high when compared to the government desire for a single interest rate regime for loans and advances. Moreover, the cash reserve ratio for banks holding public sector accounts keep increasing. This unstable policy affects granting of credit to customers and credit administration by banks.

\subsection{Research Questions}

The questions posited by the study are given below:
A. What effect does the liquidity ratio have on the loans and advances of the banking Industry?
B. What impact does the cash reserve ratio have on the loans and advances of the banking system?
C. To what degree does Monetary Policy Rate (MPR) affect the loans and advances of Nigerian commercial banks?
D. What is the influence of the rate of exchange on loans and advances in the banking system?

\subsection{Objectives of the Study}

The main aim of the study is discovering the influence of monetary policy on loans and advances in commercial bank in Nigeria.

The specific objectives are:

A.) To investigate the influence liquidity ratio has on the loans and advances in the banking industry.

B.) To analyze the impact of cash reserve ratio on the loans and advances of the banking system.

C.) To get the effect of Monetary Policy Rate (MPR) on the loans and advances of Nigerian commercial banks?

D.) To investigate the influence the rate of exchange has on the loans and advances of the banking system.

\subsection{Scope of the Study}

The scope of this study will cover the period 1981-2013 (33years), in other to see the overall effect of the monetary policies implemented on loan risk exposure in the Nigerian banking system, with particular reference to the commercial banks.

This research paper is segmented into five components. The first section is the introduction. Section two contains literature review, section three contains the methodology used in the study, section four contains data presentation and analysis, finally, part five contained findings made and policy recommendations.

\section{Literature Review}

This section reviewed the relevant literature relating to the relationship between the monetary policy framework and the Banking industry sharing information under the conceptual framework, theoretical framework and empirical framework.

The conceptual framework discusses the role of the monetary policy framework in accomplishing efficiency in performance in the banking system. While the theoretical framework will support the theory propounded by ModiglianiMiller and adopt the Punita and Somaiya (2006) empirical model which is modified to suit this research study. The empirical framework will shed light on previous works done by past researchers.

The needto get funds and allocate same to fund the economic sector formed the main basis for the formulation and implementation of any nation's monetary policies. The intermediation process of the entire financial market participants need to be successful.

In a dynamic financial structure, Central Banks will not have an effectiveness monetary policy without laying out first hand procedures and tools in the long-run, the reason being that financial institutions seeking profits change or 
produce new tools so as to avoid rules or react to dynamic conditions in the economy. (Kogar 1995). The cost of borrowing funds (interest rate) and the supply of money in its totality assist in shaping the direction of monetary policy. Monetary policies are encompassing, if the rate of interest placed by monetary authorities are envisioned to give rise to growth in the economy; neutral if the intention is not to creating growth or fighting inflation; nor tight if its sole aim is to decrease the rate of inflation

Ubi et al (2012) as cited by Tobi and Peterside (2014) have suggested that monetary policy should be consistent and transparently defined in response to the dynamics of the domestic and global economic development.

\subsection{Theoretical Framework}

The usual principle in investigating the effect of monetary policy is the IS-LM Framework introduced by the Keynesian school of thought along a Phillips curve added to it to determine the rate of inflation. The IS-LM Model is a representation of the macroeconomy by the Keynesian school. This model takes care of equilibrium in the money market and the goods market, adopting parameters that are given, the LM line shows the money market while The IS line represents the goods market

Movements in monetary aggregates which influences the supply of money, leading to interest rate structural changes, to even out the demand for money along the supply of money. Movements in the rate of interest will then influence consumption alongside investment, consequently, transients to changes in output and then prices.

The theory adopted for this study was propounded by Modigliani-Miller where he states how monetary policy impacts on the performance of the banking system.

\subsubsection{The Modigliani-Miller Bank Lending Channel Theorem}

According to Modigliani-Miller, (1958) monetary policy has a direct impact on the supply of bank loan and advances. He states that in financing loans, these financial intermediaries also shoulder reserve requirements. For instance, where contractionary monetary policy control is being operated like in Nigeria, the Central Bank reduces the intake of reserve deposits by banks. This reduction in reserve liabilities inversely affects bank lending. For a bank lending channel to be operative, the market for non-reserve bank liabilities must be frictionless so that banks can access profitable lending opportunities.

The lending channel of banks has nothing to do with banks capital regulation or level of banks capital except in instances where a binding capital requirement exists. In this case, monetary authority's placement of policies like minimum or maximum level of capital for financial intermediaries will affect bank lending. This is because a change in a bank's capital level will have a strong effect on its lending abilities. Therefore the bank lending channel thesis by Modigliani-Miller hinges its existence on the availability of liquidity constraint in the banking system. This simply means that in the event a bank suffers cash insufficiency, illiquidity of assets or is unable to gain entrance to a frictionless market for managed liability, the need for bank lending channel will arise. The theorem further states that monetary policy actions can affect the profitability of a bank as a result of the fluctuations in open market interest rates.

\subsection{Monetary Policy in Nigeria}

CBN act 1959 clearly states that the objectives to be achieved by the CBN act to include the following: (1) Full employment attainment, (2) Long term interest rate stability 3) Optimal exchange rate target pursuance. According to Onyeiwu (2012) the cbn monetary policy in use has been charged with authority of devising and enforcing monetary policy of the cbn act (1958). The development of monetary policy is categorized in two stages: (1) direct control era (1959-1986) and (2) market-based controls era (1986-date). Direct control phase was an exceptional time in Nigeria's monetary management period. This is because it aligned with different changes in the structure of the economy. This includes economic base shift from agriculture to petroleum, civil war enforcement, the boom and crash in oil prices in both 1970s and 1980s, with the establishment of the structural adjustment programme. In this era, the monetary policies of the central bank was concentrated on putting in place and managing the rate of interest and exchange, discerning allocation to certain sectors, discount rate manipulations, finally moral suasion.

SAP commenced in 1986 and adjustments made to the CBN act in 1991 brought in a new era of implementation of monetary policy in Nigeria. This precisely guaranteed CBN goal autonomy and full instrument. Employing this method, CBN influences parameters in the economy indirectly via its OMO. The activities conducted are mainly on TB and REPOs serving a complimentary role with reserve requirements usage, Liquidity ratio and Cash Reserve Ratio. The above 
instruments set is employed to cause changes in the quantity base nominal anchor (monetary aggregates) employed in monetary programming.

In other way, the cash reserve ratio (CRR) is used as the price based nominal anchor in swaying the direction in the economy cost of fund. Movements in this rate is a signal to the banks' monetary disposition, either it is pursuing a tightening or an expansionary monetary policy. They are generally placed within $26 \%$ and $8 \%$ range from 1986 . The CBN latter established in 2006 the monetary policy rate (MPR) to replace CRR which states the rate of interest corridor added and subtract $2 \%$ point of existing MPR.

\subsection{Empirical Framework}

Different studies have been made on the relationship amongst monetary policy and the banking industry's activities which analyzes the impact of the macroeconomic stability on the lending activities of banks. The studies made in this area are reviewed in this section..

Gertler and Gilchrist (1994) focused on the reaction of bank lending to tightened monetary policy showed that the banking business does not become worse as a result of these tightening. However, the conclusion made was that the overall decrease in lending arises totally from reduced real estate and consumer loans, contrary to Gertler and Gilchrist (1994) a study undertaken by Kashyap and Stein (1995) undertook a study which posits that business lending could act in response to monetary policy tightening and that loans of small banks fall while the loans at big banks remain untouched.

Punita and Somaiya (2006) examined monetary policy impact on the profitability of banks in India (1995-2000). Variables used to capture monetary policy include bank rates, lending rates, cash reserve ratio, and statutory ratio regressed autonomously on banks profitability. The rate at which loans were given out was attested to have significantly affected banks' profitability positively. This signified that a decline in the rate of lending would cause a decline in profitability of banks. It was also noticed that bank rate, cash reserve ratio and statutory ratio integrated to state the relationship between bank profitability and the instruments of monetary policy in the private sector.

Amidu and Wolfe (2008) studied monetary policy implications on banking lending in Ghana (1998-2004). The research show that banks behaviour in Ghana is highly affected by the economy of the country as well as the change in supply of money. Their work supports the position of previous research done that state how central bank prime rate and inflation rate adversely affects bank lending.

\section{Methodology}

The major aim of this paper is investigating the dynamic casual relationship amongst deposit money banks, loan risk exposure and monetary policy variables of liquidity ratio; cash reserve ratio, monetary policy rate and exchange rate for developing economy such as Nigeria. The foreign exchange rate variable in the model analysis was considered necessary for assessing the dynamic nature of the interaction of these variables with the external trade sector in the macroeconomic environment. The study is based on multivariate perspective within the confinement of a vector error correction model (VECM) framework. Annual time series observations for the ratio of the sum of treasury bills and demand deposits to total loan and advances was used as proxy for loan risk exposure (LRE) of the banks, liquidity ratio $(\mathrm{LR})$ was proxy for financial performance ratio, minimum rediscount rate for monetary policy rate (MPR) and the official naira cross exchange rate for the average foreign exchange rate (AER). The period of the study spanning from 1981 to 2012 during which the country implemented the structural adjustment programme (SAP) as part of its economic stabilization program. All variables are in natural logarithms transformation.

\subsection{Model Specification}

The functional model showing the relationship between loan risk o deposit money banks and monetary policies in Nigeria is implicitly specified as follows;

$L R E=f(L R, C R R, M P R, A E R)$ Eqn (1)

However the linear form of the above model is expressed explicitly as;

LLRE $=\beta_{0}+\beta_{1} L L R_{t}+\beta_{2} L C R R_{t}+\beta_{3} L M P R_{t}+\beta_{4} L A E R_{t}+\mu_{t} \ldots .$. Eqn (2)

Where,

LLRE is loan risk exposure of bank (Dependent variable, $Y_{t}$ )

The independent variables $\left(X_{t}\right)$ associated with the model are represented as follows; 


\author{
LLR is Liquidity ratio \\ LCRR is Cash Reserve ratio \\ LMPR is Monetary Policy rate \\ LAER is Average exchange rate \\ Bois the constant term on the $\mathrm{Y}$-axis \\ $t$ denotes time series observation \\ $\mu_{t}$ is the stochastic error term \\ $\beta_{1} \ldots \beta_{4}$ are the estimated regression co-efficient
}

\title{
3.2 Estimation Technique
}

\subsubsection{Unit Root Test}

One of the assumptions for existence of co integration is that all variables of the model equation be integrated to the same order. In other words, all the series are expected to exhibit a deterministic trend behavior. Two popular set of unit root test were utilized to test the order of integration of the variables - Philip Peron (PP) and Augmented Dickey Fuller test (ADF) tests with their results as presented in table 1 below.

\subsubsection{Co integration Procedure}

The co integration test establishes the existence or otherwise of a long run relationship among series of the variables included in the model equation. The confirmation of at least one or more co integrated equations is an indication that all the variables will tend to be co integrated at in the long run though they could be a mix of level and non-stationary trended data series currently present in the model. The co integration is the pre-condition which is normally conducted to determine the long run equilibrium state of the data prior to the application of vector error correction method. This is informed by the argument that the co integration test is based on the assumption that there is an existence of linear trends in the series. In other words the model allows the drifting of the non-stationary relations associated with its equation. Following the result of the co integration we can conclude that there exists at least one co integrating vector or otherwise. The existence of a co integrating equation implies that the included cases of ' $n$ ' variables are being held together by long run relationship among the series. In this process, the number of the residual series and invariably the error term is predetermined from the number of co integrating vectors. In this the Johansen (1988) and Johansen and Juselius (1990) procedure is examined. The superiority of this technique derives from its estimation technique which employs two test statistics of trace and maximum Eigen value in the determination of co integrating equation relationships in the model. It further identifies the number of co integrating relations attributed to the estimated equation.

Application of the Johansen co integration procedure in testing for the long run relationship among the variables employed in this study creates an avenue for the utilization of the error correction terms derived from the co integrating vectors in the long run equation, Johansen and Juselius, (1990). Since the VECM estimation incorporates multiple co integrating relationships and the error corrections terms, it could thus be a plausible procedural approach for dynamic multivariate empirical investigation of this kind.

\subsubsection{Vector Error Correction}

The identification of a co integrating relationship among the variables wherefore is an indication for an existence of an error correction representation of the model estimation. The presence of an error correction term further suggest that the variation in the endogenous variable are explained by the equilibrium disturbances in the in the long run co integrating equation. These changes are confirmed from the error terms and the variations from other exogenous variables in the model. The error correction term(s) basically captures the rate of adjustment process towards the long run equilibrium state.

Although the Johansen co integration procedure indicates presence or absence of co integrating equations, it does not does not reflect the direction of causality. This is normally included in the estimated vector error correction result. The error correction terms represents the short run adjustment process to the long-run equilibrium state. The higher the error correction terms the better the speed of adjustment within a specific period. The magnitude of the error correction terms ranges between zero $(0)$ and one (1) expressed in percentage and should be negatively signed with statistically significant T-value for an acceptable adjustment process to be achieved. The error correction terms arising from the co 
integrating vectors are derived from the study using the Johansen multivariate co integration procedure. The lagged levels of the error correction terms incorporated among the pre-determined variables of the error correction model analysis as part of the exogenous determinants. The introduction of error correction model obtained from the co integrating equation as the lagged error correction terms captures the lost long run information as a result of the differenced trend stationary series of the estimated model. The advantage of this approach relates not only to the confirmation of the existence of a co integrating relationship or otherwise among the variables derived from the Johansen procedure. It further identifies the nature and direction of the adjustment effect. This also informs the significance of the vector error correction methodology particularly in econometric analysis of multivariate system dynamic relationships.

\section{Data and Empirical Results}

\subsection{Unit root Result}

Analysis of the result in table 1 shows that the presence of a unit roots for the variables cannot be rejected at levels.

Table 1: Unit Root Test

\begin{tabular}{|c|c|c|c|c|c|c|}
\hline & \multicolumn{2}{|c|}{ First Difference } & & \multicolumn{2}{c|}{ Levels } & \\
\hline Variables & ADF-Statistic & PP-Statistic & Remarks & ADF-Statistic & PP-Statistic & Remarks \\
\hline LLR & -5.867075 & -5.867075 & Stationary & -3.194735 & -3.194735 & Stationary \\
\hline LCRR & -4.031272 & -4.031272 & Stationary & -1.928882 & -2.121474 & Non Stationary \\
\hline LMPR & -4.659029 & -6.423540 & Stationary & -2.756516 & -2.754753 & Non Stationary \\
\hline LAER & -4.982787 & -4.982787 & Stationary & -1.841566 & -2.030741 & Non Stationary \\
\hline LLRE & -5.418737 & -6.459297 & Stationary & -1.899761 & -1.852125 & Non Stationary \\
\hline ADF and PP critical values at 5\% are - -2.960411 and -2.963972 for levels and first difference. \\
\hline
\end{tabular}

The evidence from the first differencing of the variables, however, reveals we cannot reject the hypothesis that all the variables are integrated to order 1 i.e. I(1). This implies that the variables were non-stationary in levels but were found to be stationary after first differencing, thus all the variables are processed as I (1) order.

\subsection{Co integration test}

The co integration relationship among the variables employed the VAR model of five variables (LLRE, LLR, LCRR, LMPR and LAER) specification for the first differenced variables with constant term in linear deterministic trend in the data. This implies that though there is an existence of none stationary relationship among the variables at levels, a linear combination of the series would allow the relationship to drift, producing a co integrated (long-run)relationship. The procedure utilized the Johansen (1988, Johansen and Juselius, 1990) reduced rank approach to determine the number of co integrating equations as shown in table 2.

Table 2: Unrestricted Co integration Rank test

\begin{tabular}{|c|c|c|c|c|c|c|c|}
\hline $\begin{array}{c}\text { Hypothesized } \\
\text { No. Of CE(s) }\end{array}$ & Max-Eigen Statistics & $\mathbf{0 . 0 5}$ Critical Value & ${\text { Prob. }{ }^{* *}}^{*}$ & $\begin{array}{c}\text { Hypothesized } \\
\text { No. Of CE(s) }\end{array}$ & Trace Statistic & $\mathbf{0 . 0 5}$ Critical Value & Prob.** \\
\hline None* & 37.9272 & 33.87687 & 0.0155 & None $^{*}$ & 87.14988 & 69.8188 & 0.0011 \\
\hline At most 1 & 19.9483 & 27.58434 & 0.3447 & At most $1^{*}$ & 49.22269 & 47.8561 & 0.0370 \\
\hline At most 2 & 19.7176 & 21.13162 & 0.0779 & At most 2 & 29.27432 & 29.7970 & 0.0573 \\
\hline At most 3 & 7.53378 & 14.26460 & 0.4281 & At most 3 & 9.556663 & 15.4947 & 0.3164 \\
\hline At most 4 & 2.02288 & 3.841466 & 0.1549 & At most 4 & 2.022880 & 3.84146 & 0.1549 \\
\hline Maximum Eigen and Trace test indicates 1 co integrating eqn(s) at the 0.01 levels. \\
\hline
\end{tabular}

Sequel to the result in table 2, we could observe that there exits at least one co integrating equation for both the maximum Eigen value and trace statistic. This reveals that the variables are held bound by long run equilibrium relationship. 


\subsection{Normalized co integrating relationship}

The result of the normalized co integrating vectors as shown in table 3 indicates a significant long run relationship between loan risk exposure (LRE) and monetary policies as the explanatory variables.

Table 3: Normalized Co integrating Coefficient (Transposed)

\begin{tabular}{|c|c|c|c|c|c|}
\hline \multicolumn{6}{|c|}{ Normalized co integrating coefficients (Standard error in parenthesis) } \\
\hline LLRE & LLR & LCRR & LMPR & LAER & Log likelihood \\
\hline \multirow{2}{*}{1.000000} & 1.846609 & -0.105388 & 0.164100 & -0.354611 & 16.52598 \\
& $(0.49588)$ & $(0.13680)$ & $(0.27425)$ & $(0.04546)$ & \\
\hline & {$[3.72390286]$} & {$[-0.77038012]$} & {$[0.59835916]$} & {$[-7.80050594]$} & \\
\hline
\end{tabular}

Note: Standard error and T-statistics are stated in parenthesis as () and [] respectively

Evidence from the estimated relationship suggests a significant positive relationship between LLRE and LLR. This implies that banks with high liquidity level will be more at risk with their loan and advances to customers. This could be further explained by the reason that high liquidity banks will tend to embark on more risky venture so as to maximize higher profit for the firm. The result of the co integrating relationship provides no significant evident in support of a long run relationship between loan risk exposure, cash reserve ratio and monetary policy rate, hence may not be reliable for efficient policy implementation. However, the estimated co efficient for exchange rate supports significant inverse relationship with risk exposure. This means that increase in the value of local currency in the international market could serve as control measure for investment risk linked with macroeconomic uncertainty. Also increase in the country's currency value would encourage more saving and investment with the financial institutions due to increase in the stability of the local currency which could reduce the level of loan risk exposure in Nigerian deposit money banks due to high currency volatility.

\subsection{Vector Error Correction Estimate}

The vector error correction term(s) is derived from the number of co integrating vectors as shown in table 2 andreflected in estimated result from the number of residual series. These are consequently incorporated as independent variables presented in their lagged-levels as part of the vector error correction model (VECM) depicted in table 4 below.

Table 4: Vector Error Correction Model Estimates

\begin{tabular}{|l|c|c|c|c|c|}
\hline Variable & D(LLRE) & D(LCRR) & D(LLR) & D(LMPR) & D(LAER) \\
\hline ECM $(-1)$ & -0.83880 & 3.864845 & -2.100285 & 0.434961 & 0.003724 \\
\hline Standard Error & $(0.32322)$ & $(3.11089)$ & $(1.75965)$ & $0.14227)$ & $(0.04162)$ \\
\hline T-Statistic & {$[-2.59513]$} & {$[1.24236]$} & {$[-1.19358]$} & {$[3.05733]$} & {$[0.08949]$} \\
\hline
\end{tabular}

Not with standing the evidence that Johansen co integration portrays the presence of the co integrating vectors, it does not necessarily reveal the nature of the adjustment process in the system. This is achieved by the analysis of the result of VECM shown in the above table. The significance of the error correction term shows that the mechanism of short-run endogenous adjustment towards the long term state in bringing the system back to its original state will be dominated by LLRE and LLR variables. Furthermore, the statistical significance of the F-tests reveals the strict exogeneity of LLR and LMPR variables. The significance of the T-tests of the lagged error correction for LLR co integrating equation indicates an adjustment speed of 55.6 percent per period of restoring the system back to equilibrium from the disequilibrium shocks. The empirical evidence emanating from the error correction coefficient shows that over 60 percent of the disturbances from the external context would be resolved per time in the short run adjustment process.

\section{Findings, Conclusion and Recommendation}

\subsection{Findings}

This study is focused on establishing the long run and dynamic relationship between loan risk exposure and monetary policies in deposit money banks in Nigeria. In the course of this study, the unit root test, co integration and error 
correction techniques were utilized in its method of data analysis.

The empirical result from this study reveals that banks liquidity has a significant positive relationship with deposit money bank level of risk exposure. This implies that banks with high liquidity have the tendency of embarking on highly risky ventures in a bid to earn high profit for the firm.

Macroeconomic variable of exchange rate plays a significant role in loan risk management of Nigerian banks. Exchange rate appreciating resulting in the increase in the value of the country's local currency in the international market could serve as a means for checking inflation that erodes the value of money. Hence increase in exchange rate in favor of naira currency could be an indication of improvement in macroeconomic stability necessary for attraction of both local and foreign investment necessary for financial development. This will also help in reduction of loan risk linked with high volatility in the value of local currency.

The estimate co efficient of Cash reserve ratio and monetary policy of minimum rediscount ratefrom the normalized co integrating relationship reveals no significant relationship with loan risk exposure of deposit money banks in the long run.

The evidence from the error correction co efficient suggests that loan risk management and liquidity performance in banks play a dominant role in restoring the system from disequilibrium errorto the long run steady state and thus bears the burden of receiving external shocks on the system.

\subsection{Conclusion}

The main purpose of this empirical research is to determine the dynamic relationship between monetary policy measures such as liquidity ratio, cash reserve, monetary policy rate, exchange rate and loan risk exposure in Nigerian deposit money banks. The research methodology employs the co integration and error correction mechanism in capturing the long run relationship and endogeneity of the bank's loan risk exposure in a systemic adjustment context. The analysis of the result in the study provides evidence that monetary policy measures adopted and implemented by the financial institutions has long lasting effect on level of risk associated with the management of loans and advances in deposit money banks in Nigeria. This study has established the fact that banks liquidity has a significant positive relationship with their level of risk exposure. Based on this fact, the banks may be tempted to embark on risky ventures since the funds are available to them. The banks are actually more interested in making more profit and not just taking risky ventures. Generally, they watch the direction of the monetary policy rate (MPR) as set by the Central bank of Nigeria (CBN) in setting their interest rate, since this rate shows whether the CBN want a tight or loose money supply in the economy. This study is in agreement with previous work which state that Central Bank's prime lending rate has effect on bank lending.

\subsection{Recommendations}

The following recommendations have been proffered based on the findings of the study:

Having observed that there is a significant long run relationship between bank liquidity performance, exchange rate and loan risk exposure of deposit money banks in Nigeria, it therefore becomes pertinent that monetary authorities implement policies that will enhance the their performance and also reduce bank lending risk.

There is need for an adoption of adequate policy measure to strengthen and improve loan risk management in Nigerian banks through supervision and enlightenment strategies by the central banks of Nigeria and other monetary authorities in charge of financial institutions in Nigeria.

The study also recommends that policies in regard to management of risk associated with loan and advances should constitute an integral part of the major management objectives of Nigerian deposit money banks.

The liquidity level of deposit money banks should be properly monitored and proactive measure put in place to safeguard banks against financial strain and losses associated with default risk in bank loan and advances.

Cash reserve ratio and monetary policy rate should be revisited with the main objective of utilizing these policy instruments in the effective control of level of risk exposure in management of bank's credit loans.

\section{References}

Ajayi F.O. and Atanda A.A.(2012). Monetary Policy and Bank Performance in Nigeria: ATwo-Step Cointegration Approach African Journal of Scientific Research Vol. 9, No. 1

Amidu M and Wolfe S (2008). The Impact of Monetary Policy on Banks Credit in Ghana'. IAABD 2008 Proceeding, Track 1.

Central Bank of Nigeria (2010) Annual Report and Statement of Account, CBN,Abuja. Pp.60 - 77 
Central Bank of Nigeria (2011).Statistical Bulletin, Golden Jubilee Edition, December,2011.

Central Bank of Nigeria (2011) Monetary Programme: Understanding Monetary Policy series N0.1 pp. 1-48

Gertler, M. and Gilchrist, S. (1994). The Role of Credit Market Imperfections in the Monetary Transmission Mechanism: Arguments and Evidence. Scandinavian Journal of Economics, Volume 95, No. 1.

Johansen S. (1992). Statistical Analysis of Co integration vectors, Journal of Economic dynamics and Control, vol.12 pp 231-51.

Johansen S. and K. Juselius (1990). Maximum Likelihood Estimation and Inference on co integration-with application to the Demand for money. Oxford Bulletin of Economics, 52, 211-244

Kashyap, A. K. and Stein, J. C. (1995). The Impact of Monetary Policy on Bank Balance Sheets. Carnegie-Rochester Conference Series on Public Policy, 42:151-195.

Kogar, C. (1995). Financial innovations and monetary controlThe Central Bank of The Republic of Turkey Discussion Paper No: 9515, May.

Modigliani F, and Merton M. (1958). The Cost of Capital, Corporation Finance and the Theory of Investment, The American Economic Review pp. 261-97.

Omankhanlen A.E (2014).The Effect of Monetary Policy on The Nigerian Deposit Money Bank System.International Journal on Sustainable Economies Management Vol. 3 No 1 Pp 39-52 Onyeiwu C (2012).Monetary Policy and Economic Growth of Nigeria Journal of Economics and Sustainable Development Vol. 3 No.7

Punita.R. and K.J. Somaiya (2006).Monetary Policy: Its Impact on the Profitability of Banks in India' Intermediate Business and Economics Research Journal; Volume 5, Number 3, Pg. 15- 19.

Thomas R.L (1993). Introductory Econometrics: Theory and Applications, Longman, London.

Toby A.J. and Peterside D. (2014).Monetary Policy, Bank Management and Real Sector Finance in Nigeria: Who is to Blame? Proceedings of the First Middle East Conference on Global Business, Economics, Finance and Banking (ME14 DUBAI Conference) Dubai, 10-12 October 2014

\section{Appendix}

\begin{tabular}{lccccc} 
YEAR & LRE & CRR & LR & MPR & AER \\
1981 & 8582.9 & 9.5 & 38.5 & 6 & 0.6369 \\
1982 & 10275.3 & 10.7 & 40.5 & 8 & 0.6702 \\
1983 & 11093.9 & 7.1 & 54.7 & 8 & 0.7486 \\
1984 & 11503.6 & 4.7 & 65.1 & 10 & 0.8083 \\
1985 & 12170.2 & 1.8 & 65 & 10 & 0.9996 \\
1986 & 15701.6 & 1.7 & 36.4 & 10 & 3.3166 \\
1987 & 17531.9 & 1.4 & 46.5 & 12.8 & 4.1916 \\
1988 & 19561.2 & 2.1 & 45 & 12.8 & 5.3530 \\
1989 & 22008 & 2.9 & 40.3 & 18.5 & 7.6500 \\
1990 & 26000.1 & 2.9 & 44.3 & 18.5 & 9.0001 \\
1991 & 31306.2 & 2.9 & 38.6 & 14.5 & 9.7545 \\
1992 & 42736.8 & 4.4 & 29.1 & 17.5 & 19.6609 \\
1993 & 65665.3 & 6 & 42.2 & 26 & 22.6309 \\
1994 & 94183.9 & 5.7 & 48.5 & 13.5 & 21.8861 \\
1995 & 144569.6 & 5.8 & 33.1 & 13.5 & 21.8861 \\
1996 & 169437.1 & 7.5 & 43.1 & 13.5 & 21.8861 \\
1997 & 385550.5 & 7.8 & 40.2 & 13.5 & 21.8861 \\
1998 & 272895.5 & 8.3 & 46.8 & 14.3 & 21.8860 \\
1999 & 322764.9 & 11.7 & 61 & 18 & 92.5284 \\
2000 & 508302.2 & 9.8 & 64.1 & 13.5 & 109.5500 \\
2001 & 796164.8 & 10.8 & 52.9 & 14.3 & 112.4864 \\
2002 & 954628.8 & 10.6 & 52.5 & 19 & 126.4000 \\
2003 & 1210033 & 10 & 50.9 & 15.7 & 135.4067 \\
2004 & 1519243 & 8.6 & 50.5 & 15 & 132.6700 \\
2005 & 1976711 & 9.7 & 50.2 & 13 & 130.4000 \\
2006 & 2524298 & 2.6 & 55.7 & 12.3 & 128.2700 \\
2007 & 4813489 & 2.8 & 48.8 & 8.8 & 117.9680 \\
2008 & 7799400 & 3 & 44.3 & 9.8 & 130.7500 \\
2009 & 8912143 & 1.3 & 30.7 & 7.4 & 147.6000 \\
2010 & 7706431 & 1 & 30.4 & 6.1 & 148.6700 \\
2011 & 7400028 & 4.3 & 25.8 & 9.2 & 153.1525 \\
2012 & 7800899 & 10 & 48.25 & 12 & 155.4200 \\
2013 & 9122200 & 12.0 & 63.2 & 12 & 157.3112 \\
\hline & & & & & \\
\hline
\end{tabular}

Source: CBN statistical bulletin 2014 